\title{
Renal cell carcinoma presenting with cutaneous metastasis: case report
}

\author{
Cilt metastazı ile seyreden renal hücreli kanser: Olgu sunumu
}

\author{
Zuhat URAKÇI,' Muhammet Ali KAPLAN,' Mehmet KÜÇÜKÖNER, ${ }^{1}$ \\ Ali iNAL,' ${ }^{1}$ Selver ÖZEKINCi, ${ }^{2}$ Abdurrahman IŞıKDOĞAN' \\ Departments of ${ }^{1}$ Medical Oncology, ${ }^{2}$ Pathology, Dicle Univercity Faculty of Medicine, Diyarbakir
}

\begin{abstract}
Renal cell carcinoma (RCC) skin metastasis is quite rare, seen in the rate of $1-3.3 \%$. We present here a RCC case that thrives skin metastasis after 5 years of diagnosis. A 57-year-old male patient was diagnosed as RCC 5 years ago and left nephrectomy was made. In the patient without metastasis at the diagnosis, metastasis developed 1 year after the diagnosis. The patient underwent palliative chemotherapy and radiotherapy. During follow-up of the patient, a large number of new emerging, purple red style nodular skin lesions were seen on the face and scalp. After the biopsy made from nodules, it was evaluated as skin metastasis of RCC. One month later that skin metastasis developed, the patient died. As a result, the skin metastasis of $\mathrm{RCC}$ is extremely rare, and indicator of poor prognosis.
\end{abstract}

Key words: Cutaneous metastasis; renal cell carcinoma.
Renal hücreli karsinomun (RHK) cilt metastazı oldukça nadir olup \%1-3.3 oranında görülmektedir. Biz burada tanıdan beş yıl sonra cilt metastazı gelişen bir RHK olgusu sunduk. Elli yedi yaşında erkek hastaya beş yıl önce RHK tanısı konularak sol nefrektomi yapılmıştı. Tanı anında metastazı olmayan hastada tanıdan bir yıl sonra metastaz gelişti. Hastaya palyatif amaçlı kemoterapi ve radyoterapi uygulandı. Hastanın takipleri esnasında yüzde, saçlı deride çok sayıda, yeni ortaya çıkan, kırmızı morumsu tarzda nodüler cilt lezyonları saptandı. Nodüllerden yapılan biyopsi sonucu RHK cilt metastazı olarak değerlendirildi. Cilt metastazı geliştikten bir ay sonra hasta kaybedildi. Sonuç olarak, RHK'nın cilt metastazı oldukça nadirdir ve kötü prognoz göstergesidir.

Anahtar sözcükler: Kutanöz metastaz; renal hücreli karsinom.
Renal cell carcinoma (RCC) constitutes approximately $3 \%$ of all malignancies in adults. ${ }^{[1]}$ RCC constitutes about $90 \%$ of renal tumors and is one of the most lethal urogenital cancers. ${ }^{[2]}$ In the average, $25 \%$ of RCCs are metastatic and the most common sites of metastasis are lung, lymph nodes, bone, liver, opposite kidney, adrenals and brain. ${ }^{[2]}$ RCC, skin metastasis is quite rare, seen in the rate of $1-3.3 \% .{ }^{[3]}$ For anatomic localization and lymphohematogen spread, since it is far from kidney, RCC in the head and neck skin metastasis is quite rare. ${ }^{[4]}$
We present here a RCC case that thrives skin metastasis after five years of diagnosis.

\section{CASE REPORT}

Five years ago, 57-year-old male patient with complaints of left flank pain and hematuria as a result of investigations was taken a diagnosis of RCC. Left nephrectomy operation was undergone. There was no metastasis at diagnosis. In the patient that was followed untreated, lung metastasis developed after 1 year and brain and bone metastasis developed after 2 years from diagnosis. Palliative 

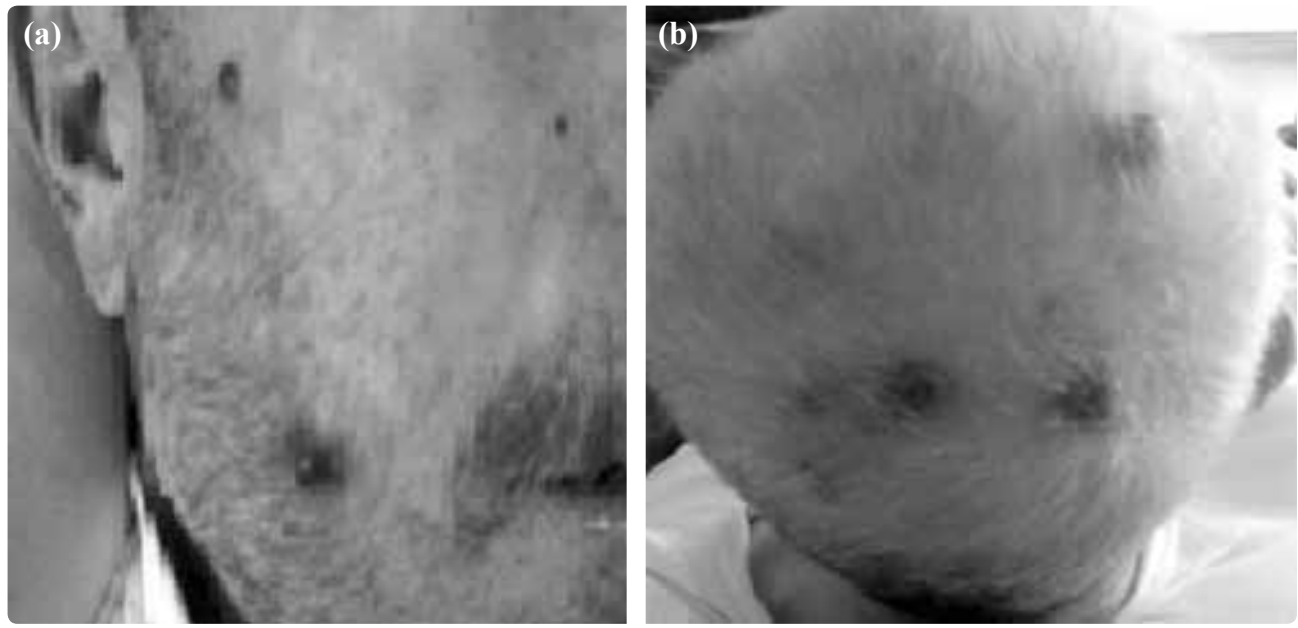

Fig. 1. (a) About $1 \mathrm{~cm}$ in diameter, small purple red style nodular metastatic skin lesions on the patient's face. (b) About $1 \mathrm{~cm}$ in diameter, small purple red style nodular metastatic skin lesions on the patient's head.

interferon-alpha was performed during the metastatic stage. Palliative radiotherapy was performed to cranium and bones. It is switched to sorafenib $200 \mathrm{mg} 2 \times 2$ therapy to the patient as determining progression under interferon. Partial response was achieved with the sorafenib therapy. During the follow-up, a large number of new emerging, nodular skin lesions were seen on the face and scalp of the patient that was treated with the sorafenib for 2.5 years. There were a large number of about $1 \mathrm{~cm}$ in diameter, small purple red style nodular skin lesions on the face and scalp (Figs. 1a, b). No other skin lesions were found in other parts of the body. In the biopsy of nodules, under microscopic squamous epithelial the atypical cells with clear cytoplasm were observed (Fig. 2a). Positive staining with EMA and vimentin were detected and metastatic RCC was reported (Figs. 2b, c). It was evaluated as skin metastasis of RCC after compared with previous preparations that were 5 years ago. The patient was given symptomatic treatment because of poor performance. The patient whose disseminated intravascular coagulation (DIC) table developed 1 month after that skin metastasis was detected died.

\section{DISCUSSION}

Skin metastasis occurs in $5-10 \%$ of high-grade
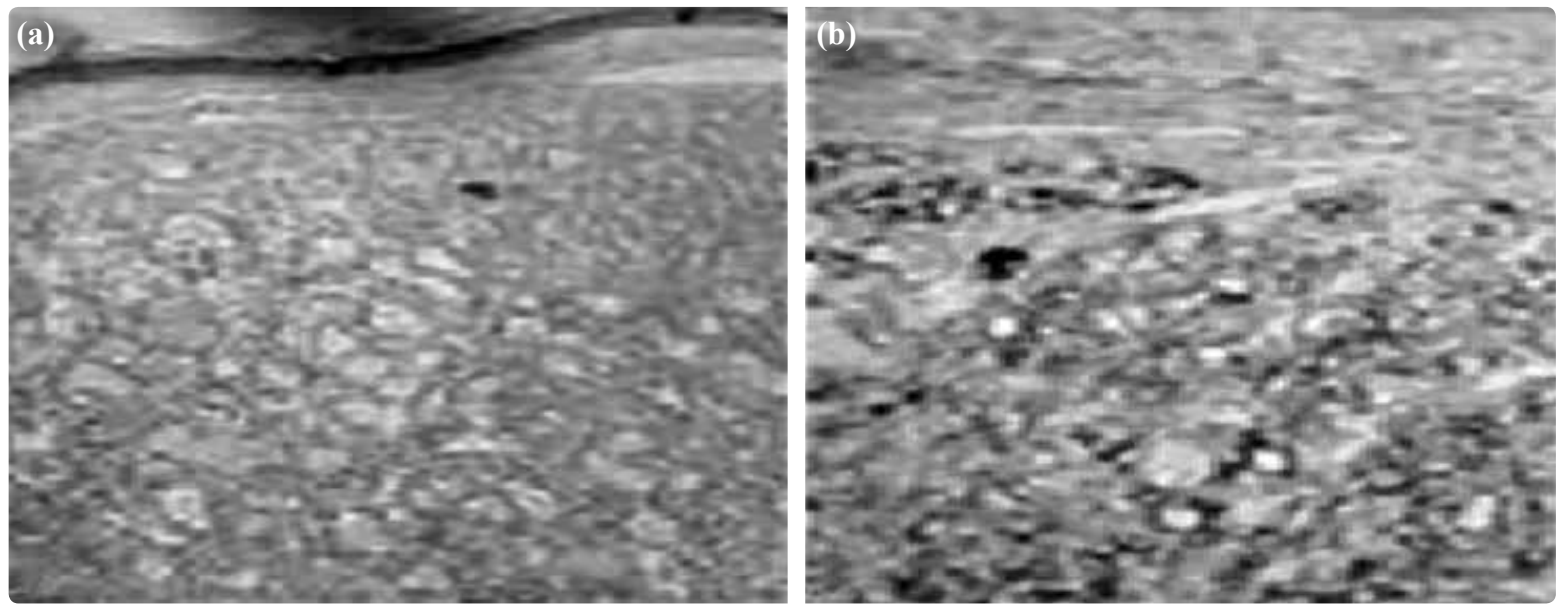

Fig. 2. a) The atypical cells with clear cytoplasm under squamous epithelial (H\&E x 200). (b) Staining cells with immunoperoxidase EMA (x200). 
malignancies. ${ }^{[4]}$ Skin metastasis is often observed in the breast, lung, colon, ovarian and malignant melanoma. ${ }^{[4]}$ Skin metastases of urogenital tumors are less frequent than in other malignancies. Urogenital tumors make skin metastasis by about $10 \%$. [5] Skin metastasis is observed approximately $3.4 \%$ in renal tumors, $0.84 \%$ in bladder tumors, $0.36 \%$ in prostate tumors and $0.4 \%$ in testicular tumors. ${ }^{[6]}$ Skin metastasis of non-RCC urogenital tumors often occurs in abdominal region. However, skin metastasis of RCC as in our case, the most frequently found in head and neck region. ${ }^{[7]} \mathrm{RCC}$ skin metastasis as in our case, is more frequent observed in males. $^{[6]}$

Skin metastasis of RCC may be solitary or multiple manner. Its view may be normal skin color, as well as, brown, black or purple due to the accumulation of hemosiderin. ${ }^{[8]}$ The view of skin metastasis of RCC is often papules, plaques or nodules. ${ }^{[7]}$ The lesions may be in milimetric size and also up to a few centimeters in size. Because of its appearance, skin metastasis of RCC may be confused with hemangioma, pyogenic granuloma, Kaposi's sarcoma, skin cysts and skin lymphoma. ${ }^{[8]}$ In our case, metastatic skin lesions were about 1 $\mathrm{cm}$ in size, red-purple in color and nodular style. The skin metastasis of RCC was diagnosed with skin biopsy.

Tumor cells are typically large, have clear cytoplasm, round or oval-core and a significant nucleolus. ${ }^{[4]}$ Immunohistochemically, epithelial cell markers such as the keratin, EMA, CEA and vimentin shows positive staining. ${ }^{[6]}$ In our case, in the biopsy of nodules, under microscopic squamous epithelial the atypical cells with clear cytoplasm were observed. Since it was determined that immunoperoxidase showed positive staining with EMA and vimentin, it was reported as metastatic RCC.

Skin metastasis of RCC is usually emerge late stage, it may emerge years after nephrectomy and sometimes before the diagnosis of renal tumors. ${ }^{[6]}$ Skin metastasis of RCC is a late stage sign, $90 \%$ together with synchronized visceral metastasis and a symptom of poor prognosis. ${ }^{[6]}$ 5-year survival rate with metastatic RCC is under $10 \%{ }^{\left[{ }^{[9]}\right.}$ There are publications specifying that the average life expectancy in cases of skin metastasis developed is less than 6 months, ${ }^{[6]}$ less than 8 months ${ }^{[7]}$ and around 12.7 months. ${ }^{[3]}$ In our case, skin metastasis developed 5 years after nephrectomy. Until the development of skin metastasis, it is remarkable that the table becomes worsening with the development of skin metastasis in the patient with lung, brain and bone metastases and dies after 1 month.

Since skin metastasis of RCC is together with disseminated disease in most cases, the therapy is limited and palliative. If there is focal skin metastasis, surgical treatment, radiotherapy, or both can be combined. ${ }^{[3]}$ Gay and colleagues reported that complete tumor regression was achieved over patient with a solitary skin metastasis of RCC with sorafenib treatment after radiotherapy. ${ }^{[10]}$ Systemic treatment is recommended to RCC patients with diffuse skin metastasis. ${ }^{[3]}$ As in our case, we have the vision that local treatments are limited in cases with diffuse skin metastasis. We stand for that he should be treated with systemic chemotherapy in appropriate cases. Due to his poor performance status, our patient was treated symptomatically.

As a result, the skin metastasis of RCC is extremely rare. It is more common in males, and head and neck region. As an indicator of poor prognosis, it should not be forgotten that purplish red skin lesions especially on head and face might be metastasis.

\section{REFERENCES}

1. Novick AC, Campbell SC. Renal tumors. In: Campbell MF, Walsh PC, Retik AB,Vaughan ED, Wein AJ, editors. Campbell's urology. 8th ed. New York: W.B. Saunders; 2002. p. 2672-731.

2. Arrabal-Polo MA, Arias-Santiago SA, Aneiros-Fernandez J, Burkhardt-Perez P, Arrabal-Martin M, NaranjoSintes R. Cutaneous metastases in renal cell carcinoma: a case report. Cases J 2009;2:7948. CrossRef

3. Kumar A, Dogra PN, Sharma MC. Isolated metachronous cutaneous metastases from renal cell carcinoma. Indian J Cancer 2010;47(4):482-3. CrossRef

4. Onak Kandemir N, Barut F, Yılmaz K, Tokgoz H, Hosnuter M, Ozdamar SO. Renal cell carcinoma presenting with cutaneous metastasis: a case report. Case Rep Med 2010. pii: 913734 . CrossRef 
5. Saeed S, Keehn CA, Morgan MB. Cutaneous metastasis: a clinical, pathological, and immunohistochemical appraisal. J Cutan Pathol 2004;31(6):419-30. Crossef

6. García Torrelles M, Beltrán Armada JR, Verges Prosper A, Santolaya García JI, Espinosa Ruiz JJ, Tarín Planes $\mathrm{M}$, et al. Cutaneous metastases of renal cell carcinoma. [Article in Spanish] Actas Urol Esp 2007;31(5):556-8. [Abstract] CrossRef

7. Liu SW, Guitart JG, Kuzel TM, Gandhi M, Lacouture M. Effect of sunitinib on renal cell carcinoma cutane- ous metastasis. Int J Dermatol 2009;48(11):1269-70.

8. Lim C, Chan R, Regan W. Renal cell carcinoma with cutaneous metastases. Australas J Dermatol 2005;46(3):158-60. CrossRef

9. Motzer RJ, Bander NH, Nanus DM. Renal-cell carcinoma. N Engl J Med 1996;335(12):865-75. CrossRef

10. Gay HA, Cavalieri R, Allison RR, Finley J, Quan WD Jr. Complete response in a cutaneous facial metastatic nodule from renal cell carcinoma after hypofractionated radiotherapy. Dermatol Online J 2007;13(4):6. 